\title{
A Circulating Myocardial Depressant Substance in Humans with Septic Shock Septic Shock Patients with a Reduced Ejection Fraction Have a Circulating Factor That Depresses In Vitro Myocardial Cell Performance
}

Joseph E. Parrillo, Cynthia Burch, James H. Shelhamer, Margaret M. Parker, Charles Natanson, and William Schuette Critical Care Medicine Department, Clinical Center, National Institutes of Health, Bethesda, Maryland 20205

\begin{abstract}
We have previously described a subpopulation of patients with septic shock who had a reversible depression of radionuclidedetermined left ventricular ejection fraction (EF). To investigate the mechanism of this myocardial depression, an in vitro model of mammalian myocardial cell performance was established employing primary spontaneously beating rat myocardial cells. The contraction of a single cardiac cell was quantitated by recording the changes in area occupied by the cell during contraction and relaxation. In 20 septic shock patients during the acute phase, the mean left ventricular EF was decreased (mean $=0.33$, normal mean $=0.50$ ), and serum obtained during this acute phase induced a mean ( \pm standard error of the mean) $33 \pm 4 \%$ decrease in extent and $25 \pm 4 \%$ decrease in velocity of myocardial cell shortening during contraction $(P<0.001)$. In contrast, serum obtained from 11 of these same patients before shock $(n=2)$ or after recovery $(n=9)$ of the left ventricular EF $($ mean $=0.50)$ showed a return toward normal in extent and velocity of shortening $(P<0.001)$. Sera from 17 critically ill nonseptic patients, from 10 patients with structural heart disease as a cause for a depressed EF, and from 12 healthy laboratory personnel, induced no significant changes in in vitro myocardial cell performance. In 20 patients during the acute phase of septic shock, the decreased EF in vivo demonstrated a significant correlation ( $r=+0.52, P<0.01$ ) with a decrease in the extent of myocardial cell shortening in vitro. The quantitative and temporal correlation between the decreased left ventricular EF and this serum myocardial depressant substance argues for a pathophysiologic role for this depressant substance in producing the reversible cardiomyopathy seen during septic shock in humans.
\end{abstract}

\section{Introduction}

Serious cardiovascular compromise resulting from bloodstream invasion by microorganisms represents one of the most common life-threatening clinical syndromes in medicine. Shock secondary to sepsis has been the subject of an enormous investigative effort during the past 40 years; however, it remains a common cause of patient demise $(1,2)$. The pathogenesis of septic shock is

Portions of this work were presented at the annual meeting of the American Federation for Clinical Research, May 1984, and were published as an abstract (1984. Clin. Res. 32:252A).

Address reprint requests to Dr. Parrillo, Critical Care Medicine Department, Building 10, Room 10D48, National Institutes of Health, Bethesda, MD 20205.

Received for publication 7 September 1984 and in revised form 1 July 1985.

The Journal of Clinical Investigation, Inc.

Volume 76, October 1985, 1539-1553 highly complex, and certain characteristics of this pathogenesis have led to considerable controversy and confusion regarding the true mechanisms of the septic shock syndrome.

Approximately 30 years ago, early studies of septic shock emphasized two distinct clinical syndromes (3). One type had a bounding pulse ascribed to a high cardiac output; a second syndrome was characterized by "cold, clammy" skin and a faint pulse and this syndrome was postulated to result from a low cardiac output. This low cardiac output was equated with inadequate heart function and was designated the heart failure or myocardial depression of septic shock (4-6). Because canine endotoxin models produced a low cardiac output, this animal model was felt to be characteristic of the low output syndrome (4). However, subsequent studies demonstrated unequivocally that most patients had a normal or high cardiac output in the initial phases of septic shock (7-15). Thus, if myocardial depression was indeed a part of septic shock in humans, a low cardiac output was not a sensitive reflection of cardiac dysfunction.

Recently, noting that the ejection fraction (EF), ${ }^{1}$ but not cardiac output, was an excellent predictor of ultimate prognosis in patients with chronic coronary disease (16), we employed both the thermodilution cardiac output and the radionuclidegated blood pool scan-determined EF in the intensive care environment, and showed that a significant subpopulation of patients with moderate-to-severe septic shock demonstrated profound reductions in left ventricular EF and concomitant dilatation of the ventricle; in patients who survived, this ventricular dysfunction was found to be reversible during a 7-10-day followup period (17). The cardiac index in these same patients was either normal $\left(2.5-3.5\right.$ liters $\left./ \mathrm{min} \cdot \mathrm{m}^{2}\right)$ or elevated $(>3.5$ liters/ $\mathrm{min} \cdot \mathrm{m}^{2}$ ). A previous study had demonstrated that 5 of 20 patients with sepsis without shock also demonstrated an initial reduction in left ventricular EF (18). Thus, by employing radionuclide studies along with thermodilution cardiac outputs, evidence of early transient myocardial depression was clearly demonstrated in humans with septic shock.

The cause of this depressed myocardial performance was not known. In animal models of hemorrhagic and endotoxic shock, two suggested mechanisms were a depressed coronary blood flow or the presence of a circulating myocardial depressant factor. Employing a thermodilution coronary sinus catheter, we found no evidence for a decrease in coronary blood flow during human septic shock (19). Thus, we devised an in vitro model of myocardial cell performance to evaluate the presence of a circulating myocardial depressant substance and attempted to correlate the presence of this in vitro substance with the radionuclide-determined EF, a measure of in vivo myocardial performance. This paper details the results of that study.

1. Abbreviations used in this paper: EF, ejection fraction; SVI, stroke volume index. 


\begin{tabular}{|c|c|c|c|c|c|}
\hline Patient code & Age & Sex & Underlying disease & Positive culture (site) & Outcome \\
\hline & $y r$ & & & & \\
\hline P1 & 54 & $\mathbf{M}$ & cerebral glioblastoma & $\begin{array}{l}\text { Klebsiella pneumonia } \\
\quad \text { (blood) }\end{array}$ & Survivor \\
\hline P2 & 24 & $\mathbf{M}$ & Lymphoma & $\begin{array}{l}\text { Clostridia septicum } \\
\quad \text { (blood) }\end{array}$ & Survivor \\
\hline P3 & 9 & $\mathbf{F}$ & Acute lymphocytic leukemia & $\begin{array}{l}\text { Pseudomonas aeruginosa } \\
\quad \text { (blood) }\end{array}$ & Survivor \\
\hline P4 & 52 & $\mathbf{M}$ & $\begin{array}{l}\text { Mediastinitis; coronary artery } \\
\text { disease }\end{array}$ & $\begin{array}{l}\text { Escherichia coli; Serratia } \\
\text { marcesans (blood) }\end{array}$ & Survivor \\
\hline P5 & 52 & $\mathbf{M}$ & Lymphoma & Escherichia coli (blood) & Survivor \\
\hline P6 & 64 & $\mathbf{M}$ & $\begin{array}{l}\text { Myocardial infarction; } \\
\text { coronary artery disease }\end{array}$ & $\begin{array}{l}\text { Pseudomonas cepacia; } \\
\quad \text { Staphylococcus } \\
\text { epidermidis (blood) }\end{array}$ & Survivor \\
\hline P7 & 57 & $\mathbf{M}$ & Lymphoma & Escherichia coli (blood) & Survivor \\
\hline P8 & 17 & $\mathbf{M}$ & $\begin{array}{l}\text { Chronic granulomatous } \\
\text { disease of childhood }\end{array}$ & $\begin{array}{l}\text { Staphylococcus aureus } \\
\text { (blood) }\end{array}$ & Survivor \\
\hline P9 & 47 & $\mathbf{M}$ & Lymphoma & Candida albicans (blood) & Survivor \\
\hline P10 & 15 & $\mathbf{F}$ & Ewing's sarcoma & $\begin{array}{l}\text { Aspergillus fumigatus; } \\
\text { Candida albicans } \\
\text { (lung) }\end{array}$ & Nonsurvivor \\
\hline P11 & 31 & $\mathbf{F}$ & Acute lymphocytic leukemia & $\begin{array}{l}\text { Klebsiella pneumonia } \\
\quad \text { (blood) }\end{array}$ & Nonsurvivor \\
\hline P12 & 27 & $\mathrm{~F}$ & Breast carcinoma & $\begin{array}{l}\text { Alpha streptococcus } \\
\text { (blood) }\end{array}$ & Survivor \\
\hline P13 & 30 & $\mathbf{M}$ & Burkitt's lymphoma & $\begin{array}{l}\text { Staphylococcus } \\
\quad \text { epidermidis (blood) }\end{array}$ & Survivor \\
\hline P14 & 55 & $\mathbf{M}$ & $\begin{array}{l}\text { Hodgkin's disease; } \\
\text { pneumonitis }\end{array}$ & $\begin{array}{l}\text { Staphylococcus } \\
\quad \text { epidermidis (sputum) }\end{array}$ & Survivor \\
\hline P15 & 64 & $\mathbf{F}$ & Lymphoma & Escherichia coli (blood) & Survivor \\
\hline P16 & 24 & $\mathbf{M}$ & Aplastic anemia & Escherichia coli (blood) & Survivor \\
\hline P17 & 61 & $\mathbf{M}$ & Chronic lymphocytic leukemia & $\begin{array}{l}\text { Pseudomonas aeruginosa } \\
\text { (blood) }\end{array}$ & Nonsurvivor \\
\hline P18 & 15 & $\mathbf{M}$ & Aplastic anemia & $\begin{array}{l}\text { Pseudomonas aeruginosa } \\
\quad \text { (blood) }\end{array}$ & Nonsurvivor \\
\hline P19 & 54 & $\mathbf{M}$ & Mycosis fungoides cellulitis & $\begin{array}{l}\text { Staphylococcus aureus } \\
\text { (skin cellulitis) }\end{array}$ & Nonsurvivor \\
\hline P20 & 54 & $\mathrm{~F}$ & Ovarian carcinoma & Candida albicans (blood) & Nonsurvivor \\
\hline Summary & Mean $=40.3$ & $\begin{array}{l}14 \text { males } \\
6 \text { females }\end{array}$ & - & - & $\begin{array}{l}14 \text { survivors } \\
6 \text { nonsurvivors }\end{array}$ \\
\hline
\end{tabular}

Patients in studies during the acute phase (P1-P20) and the recovery or presepsis phase (P1-P11) of septic shock.

\section{Methods}

Patient population. From July 1982 to December 1983, 20 patients with septic shock underwent serial studies of cardiovascular function in the Medical Intensive Care Unit at the National Institutes of Health. These patients represented all the patients admitted to the Intensive Care Unit who fulfilled the criteria for septic shock during this time period. Septic shock was defined in two ways: $(a)$ temperature $>38^{\circ} \mathrm{C}$, hypotension (mean arterial pressure $<60 \mathrm{mmHg}$ ), and positive blood cultures (17 patients); or (b) fever, hypotension, profound neutropenia (neutrophils 
$<500 \mathrm{cells} / \mathrm{mm}^{3}$ ), and a localized site of culture positive infection, but negative blood cultures that were ascribed to concomitant treatment with broad-spectrum antibiotics (three patients). The clinical characteristics of these 20 patients are shown in Table I.

Of the 20 patients with septic shock, 11 patients had serial hemodynamics, serial radionuclide scans, and serial blood drawing to allow comparison of the acute and recovery $(n=9)$ or the acute and presepsis $(n=2)$ measures of cardiovascular function; these serial tests also allowed comparison of in vivo cardiovascular function with a measure of in vitro myocardial cell performance (see below). In 9 of the 20 septic shock patients, initial hemodynamics and initial blood samples were obtained; however, serial blood samples were not obtained (due to early death or due to unavailability of personnel) and the initial values only were analyzed. These nine patients demonstrated similar serial cardiovascular parameters (i.e., a return to normal EF in survivors) as the 11 patients (P1-P11) cited above.

Control populations. Three separate control populations (Table II) were evaluated and compared with the patient population. Blood samples were obtained from 12 healthy laboratory personnel who were taking no medications and had no symptoms or signs of any cardiovascular disease. This control group was assumed to have normal cardiovascular function. A second control group consisted of 10 patients with chronic cardiovascular disease that had resulted in a decreased resting $\mathrm{EF}(<0.45)$. These patients were being evaluated electively for their cardiovascular disease and had no signs of acute illness and no evidence of sepsis. A third control group consisted of 17 critically ill patients admitted to the National Institutes of Health Medical Intensive Care Unit for intensive medical care. None of these patients had known structural heart disease and none had suspected bacterial or fungal sepsis. All 17 patients had initial (14 patients had serial) radionuclide-determined EFs in the normal range $(0.45-0.72)$.

Hemodynamic evaluations. In the patients and the critically ill controls, arterial pressure was monitored by an indwelling arterial catheter in the radial or femoral artery. A pulmonary artery balloon flotation catheter was positioned with fluoroscopic guidance in the pulmonary artery of each patient. Serial measurements (every 6-12 h) of central venous pressure, pulmonary capillary wedge pressure, and cardiac output by thermodilution technique were obtained. Cardiac index was the cardiac output divided by a patient's body surface area. Measurements of pulmonary capillary wedge pressure were made from tracings on graph paper at end expiration. In patients on positive end expiratory pressure (see below), measurements of pulmonary capillary wedge pressure were made at end expiration both on and after $10 \mathrm{~s}$ off positive and expiratory pressure. In the patients in this study, the mean pulmonary capillary wedge pressure on and off positive end expiratory pressure never differed by $>2 \mathrm{mmHg}$.

Systemic vascular resistance index (SVRI) and stroke volume index (SVI) were calculated according to standard formulas: SVRI (dynes $\cdot \mathrm{s} /$ $\left.\mathrm{cm}^{-5} / \mathrm{m}^{2}\right)=($ MAP $-\mathrm{CVP}) \div(\mathrm{CI}) \times 80$, and SVI $\left(\mathrm{ml} /\right.$ beat $\left.\cdot \mathrm{m}^{2}\right)=\mathrm{Cl}$ $\div \mathrm{HR}$, where MAP $=$ mean arterial pressure, $\mathrm{CVP}=$ central venous pressure, $\mathrm{CI}=$ cardiac index, and $\mathrm{HR}=$ heart rate.

Therapeutic protocol. All the patients and any hypotensive critically ill control patient were treated by the same group of critical care physicians employing the following sequential treatment protocol: the goal was to maintain a mean arterial pressure $>60 \mathrm{mmHg}$. Initially, all patients received intravenous fluids to maintain a pulmonary capillary wedge pressure of $15 \mathrm{mmHg}$. Dopamine was then added if the patient remained hypotensive. If the patient required $>20 \mu \mathrm{g} / \mathrm{kg} \cdot \min$ of dopamine, levarterenol was added, and the dopamine was tapered to $2-3 \mu \mathrm{g} / \mathrm{kg} \cdot \mathrm{min}$ in an attempt to preserve renal perfusion. All patients received broadspectrum antibiotic coverage, usually including an aminoglycoside, a cephalosporin, and a semisynthetic penicillin active against Pseudomonas aeruginosa. When blood culture results were obtained, the antibiotic agents were adjusted appropriately. Each patient in shock was given two doses of methylprednisolone, $30 \mathrm{mg} / \mathrm{kg}$ of body weight, one at the onset of shock, and the second 4-8 h later. All blood specimens were obtained at least $2 \mathrm{~h}$ after any infusion of corticosteroids or antibiotics. Respiratory support was given as needed to maintain a normal $\mathrm{pH}$ and an arterial partial pressure of oxygen $\left(\mathrm{PO}_{2}\right)>70 \mathrm{mmHg}$; all studies were done when arterial $\mathrm{PO}_{2}$ and $\mathrm{pH}$ were normal. Of the 20 septic shock patients during the acute phase, 12 were on mechanical ventilation, and 4 were on mechanical ventilation during the recovery phase of their illness.

Metabolic parameters, including serum electrolytes (sodium, potassium, bicarbonate, chloride), phosphate, calcium, magnesium, and glucose, were frequently (usually every 4-6 h) determined and any abnormalities were promptly corrected. Serum levels of metabolites are considered further below.

Cardiovascular studies employing radionuclide cineangiography. Initial and serial radionuclide cineangiography studies were performed on septic shock patients and critically ill controls; initial radionuclide studies only were performed on control patients with structural heart disease. The initial study was always done as near to the onset of shock (or the critical illness precipitating intensive care unit admission) as was technically and medically feasible, always within the first $24 \mathrm{~h}$. Followup studies were performed every 2-3 d up to $10 \mathrm{~d}$ after the acute phase of the illness. A recovery scan was defined as a scan performed at least $5 \mathrm{~d}$ after clinical recovery from the acute illness or a scan demonstrating recovery to an EF level comparable to a patient's presepsis EF (if known).

Electrocardiographic-gated cardiac scintigraphic examinations were performed at the patient's bedside in the medical intensive care unit using a portable Picker camera that was interfaced with a Hewlett-Packard Co. (Palo Alto, CA) computer (20). Patients received an injection of stannous pyrophosphate, and $30 \mathrm{~min}$ later received $20 \mathrm{mCi}$ of technetium$99 \mathrm{~m}$ to accomplish in vivo labeling of the patient's erythrocytes. With the patient in the supine position, the camera was positioned in a $35^{\circ}$ left anterior oblique orientation with a $15^{\circ}$ caudal tilt to isolate the left ventricle. Left ventricular and background regions of interest were labeled, and background corrected left ventricular time-activity curves were generated from the image sequence. Left ventricular $E F$ was calculated from each curve as $E F=(E D C-E S C) \div(E D C-B k g d)$, where $E D C=$ end diastolic counts, $\mathrm{ESC}=$ end systolic counts, and Bkgd = background counts. The end diastolic volume index (EDVI) and end systolic volume index (ESVI) were calculated from simultaneously obtained hemodynamic studies and ejection fractions, using the formulas: EDVI = SVI (from thermodilution cardiac output) $\div \mathrm{EF}$ (from radionuclide cineangiography) and ESVI = EDVI - SVI.

In vitro myocardial cell performance assay. We devised a modification of previously described in vitro heart cell contractility system (21-26). These systems had been shown to be affected by addition of calcium or inotropic agents and were thus felt to reflect in vivo physiology.

Spontaneously beating newborn rat heart cell cultures were established employing a modification of the technique described by Harary and Farley (21). Using sterile techniques, the ventricular muscle was dissected away from the atria and great vessels, cut into small $1-\mathrm{mm}^{3}$ blocks of tissue, and exposed to trypsinization ( $0.05 \%$ trypsin in modified Hanks' balanced salt solution without $\mathrm{Ca}^{++}$or $\mathrm{Mg}^{++}$) for 8 -min periods at $37^{\circ} \mathrm{C}$; the suspension was centrifuged at $1,500 \mathrm{rpm}$ to pellet the tissue and cells, then resuspended in $0.05 \%$ trypsin for another incubation. Usually two to five incubation plus centrifugation steps were necessary to produce single-cell suspensions.

The myocardial cell suspension was brought up in culture media consisting of the following: potassium-free balanced salt solution (Dulbecco's BSS-K) 65\%; Medium 199, 25\% (Grand Island Biological Company, Grand Island, NY) supplemented with $1,000 \mathrm{U}$ penicillin, 1,000 $\mu \mathrm{g}$ of streptomycin, and $10 \mathrm{~mm}$ of glutamine; and $10 \%$ heat-inactivated $\left(56^{\circ} \mathrm{C}\right.$ for $\left.30 \mathrm{~min}\right)$ newborn calf serum. The cell suspension was placed into $35 \times 10$-mm petri dishes (Falcon Premaria-Becton Dickinson, Oxnard, CA) at a cell suspension of $3 \times 10^{5}$ cells/2-ml dish. Cells were incubated at $37^{\circ} \mathrm{C}$ in an atmosphere of $95 \%$ air plus $5 \% \mathrm{CO}_{2}$ and $100 \%$ humidity. Growth media was changed after $48 \mathrm{~h}$ of incubation, and cells gained near-confluence and began spontaneous beating rates $(30-80$ beats $/ \mathrm{min}$ ) at 3-6 d after inoculation. Beating cells were used in the assay at 4-8 $\mathrm{d}$ postinoculation.

The extent and velocity of myocardial cell shortening during contraction was assayed by a modification of previously described techniques (27). Fig. 1 depicts a schematic diagram of our myocardial cell perfor- 
Control group I: Normal laboratory personnel $(n=12)$

Age range: $28-38 \mathrm{yr}$, mean $=34.6 \mathrm{yr}$

Sex distribution: 7 males, 5 females

No symptoms or signs of cardiovascular disease

At the time of the study, no person was taking any medication.

Control group II: Decreased EF due to structural heart disease

\begin{tabular}{lllll}
\hline Patient code & Age & Sex & Underlying disease & Left ventricular EF (at rest) \\
\hline & $y r$ & & & \\
CII-1 & 53 & M & Coronary artery disease & 0.36 \\
CII-2 & 54 & M & Coronary artery disease & 0.30 \\
CII-3 & 61 & M & Coronary artery disease & 0.26 \\
CII-4 & 73 & F & Coronary artery disease & 0.39 \\
CII-5 & 48 & M & Coronary artery disease & 0.27 \\
CII-6 & 60 & F & Aortic regurgitation & 0.37 \\
CII-7 & 43 & F & Mitral and tricuspid & 0.24 \\
CII-8 & 50 & M & valve replacement & 0.19 \\
CII-9 & 45 & F & Aortic rergurgitation & 0.32 \\
CII-10 & 52 & F & Adriamycin & 0.18 \\
& & & Cardiotoxicity & Mean \pm SEM \\
Summary & Mean $=53.9$ & 5 males & mitral regurgitation & $0.288 \pm 0.023$
\end{tabular}

Control group III: Critically ill nonseptic patients*

\begin{tabular}{|c|c|c|c|c|c|}
\hline Patient code & Age & Sex & Underlying disease & Left ventricular EF & Outcome \\
\hline & $y r$ & & & & \\
\hline CIII-1 & 41 & $\mathbf{M}$ & Pneumocystis pneumonia $†$ & 0.56 & Nonsurvivor \\
\hline CIII-2 & 25 & $\mathbf{M}$ & $\begin{array}{l}\text { Hypovolemic shock; Ewing's } \\
\text { sarcoma }\end{array}$ & 0.52 & Survivor \\
\hline CIII-3 & 29 & $\mathbf{F}$ & $\begin{array}{l}\text { Hemorrhagic shock; breast } \\
\text { carcinoma }\end{array}$ & 0.51 & Survivor \\
\hline CIII-4 & 71 & $\mathbf{F}$ & $\begin{array}{l}\text { Respiratory failure; chronic } \\
\text { lymphocytic leukemia }\end{array}$ & 0.45 & Nonsurvivor \\
\hline CIII-5 & 55 & $\mathbf{M}$ & $\begin{array}{l}\text { Pneumocystis pneumonia; } \\
\text { leukemia }\end{array}$ & 0.45 & Nonsurvivor \\
\hline CIII-6 & 48 & $\mathbf{M}$ & $\begin{array}{l}\text { Pneumocystis pneumonia; } \\
\text { lymphoma }\end{array}$ & 0.79 & Nonsurvivor \\
\hline CIII-7 & 62 & $\mathbf{F}$ & $\begin{array}{l}\text { Respiratory failure; systemic } \\
\text { vasculitis }\end{array}$ & 0.46 & Survivor \\
\hline CIII-8 & 34 & $\mathbf{M}$ & $\begin{array}{l}\text { Bleomycin-induced respiratory } \\
\text { failure; testicular carcinoma }\end{array}$ & 0.46 & Nonsurvivor \\
\hline CIII-9 & 62 & $\mathbf{F}$ & Respiratory failure; lymphoma & 0.62 & Nonsurvivor \\
\hline CIII-10 & 55 & $\mathbf{F}$ & $\begin{array}{l}\text { Cardiogenic shock; severe } \\
\text { hypertrophic cardiomyopathy }\end{array}$ & 0.57 & Survivor \\
\hline CIII-11 & 23 & $\mathbf{M}$ & $\begin{array}{l}\text { Bleomycin-induced respiratory } \\
\text { failure; testicular carcinoma }\end{array}$ & 0.64 & Nonsurvivor \\
\hline CIII-12 & 59 & $\mathbf{F}$ & $\begin{array}{l}\text { Hypovolemic shock; mitral } \\
\text { valve replacement }\end{array}$ & 0.70 & Survivor \\
\hline CIII-13 & 26 & $\mathbf{M}$ & $\begin{array}{l}\text { Radiation pneumonitis and } \\
\text { respiratory failure; lymphoma }\end{array}$ & 0.46 & Nonsurvivor \\
\hline CIII-14 & 33 & $\mathbf{M}$ & $\begin{array}{l}\text { Hepatic and renal failure; } \\
\text { Hodgkin's disease }\end{array}$ & 0.64 & Nonsurvivor \\
\hline CIII-15 & 56 & $\mathbf{F}$ & $\begin{array}{l}\text { Pericardial tamponade; breast } \\
\text { carcinoma }\end{array}$ & 0.51 & Survivor \\
\hline
\end{tabular}


Table II. (Continued)

\begin{tabular}{|c|c|c|c|c|c|}
\hline Patient code & Age & Sex & Underlying disease & Left ventricular EF & Outcome \\
\hline & $y r$ & & & & \\
\hline CIII-16 & 24 & $\mathbf{M}$ & $\begin{array}{l}\text { Respiratory failure; testicular } \\
\text { carcinoma }\end{array}$ & 0.60 & Nonsurvivor \\
\hline CIII-17 & 37 & $\mathbf{M}$ & $\begin{array}{l}\text { Hepatorenal syndrome; } \\
\text { lymphoma }\end{array}$ & 0.67 & Nonsurvivor \\
\hline Summary & Mean $=43.5$ & $\begin{array}{l}10 \text { males } \\
7 \text { females }\end{array}$ & & $\begin{array}{l}\text { Mean } \pm \text { SEM } \\
\quad=0.564 \pm 0.025 \\
\text { (Normal range } \\
\quad=0.45-0.72 \text { ) }\end{array}$ & $\begin{array}{l}6 \text { survivors } \\
11 \text { nonsurvivors }\end{array}$ \\
\hline
\end{tabular}

* No patient had positive cultures for bacteria or fungi. $¥$ Pneumocystis pneumonia was diagnosed by histologic identification of Pneumocystis carinii in lung tissue.

mance assay system. Beating myocardial cells in a petri dish were placed on the microscope stage of an inverted phase-contrast microscope (Nikon Inc., Garden City, NY). A television camera (Philips Electronic Instruments, Inc., Mahwah, NJ) was attached to the microscope and displayed the image on a television monitor. An electronic video area detector was employed to analyze the movement of the myocardial cell as it contracted and relaxed. The output of the area detector was recorded on a dualchannel strip chart recorder (Cleveite Brush Mach 20; Gould Inc., Brush Div., Cleveland, $\mathrm{OH}$ ) at multiple paper speeds. A Hewlett-Packard computer electronically derived the first derivative of the extent of shortening (the velocity), which was recorded on the second channel of the strip chart.

Fig. 2 demonstrates the method employed to evaluate cell motion electronically. The edge of a contracting myocardial cell (at the end of contraction) was placed at the border of a video field. The density of the cell was greater than a specific density threshold that could be measured by the electronic circuit within the video field. The density threshold is adjustable and could be regulated to an appropriate level. Within the video field, the specific density was below that which the electronic circuit could measure. During myocardial cell relaxation, the cell (with its specific density above the measurable threshold) would occupy a significant amount of area within the video field. During contraction, the edge of the cells would move to the edge of the video field and occupy little or none of the area of the video field. The video field electronics had the ability to measure instantaneously the area within the video field above

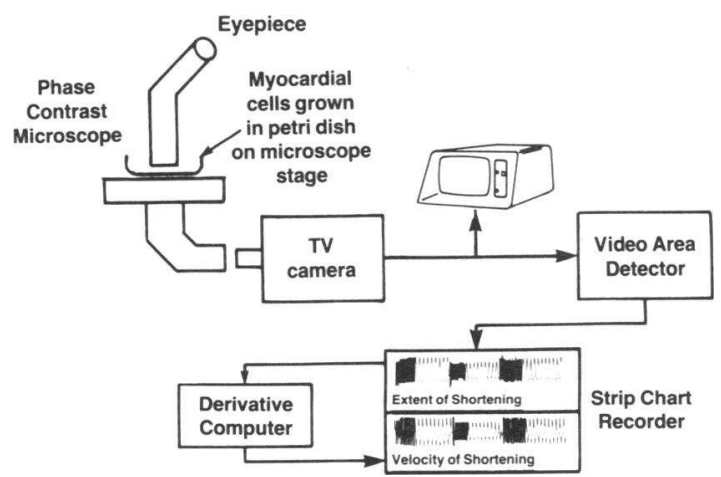

Figure 1. A schematic diagram of the myocardial cell contractility assay system. Beating rat myocardial cells grown in a petri dish were placed on the stage of a phase-contrast microscope. The beating cells were imaged by a television camera and the myocardial cell contraction was analyzed by a video area detector. The extent and velocity (first derivative of extent) of myocardial cell shortening were recorded on a strip chart. For details, see text. a specific density threshold. Thus, by plotting time versus the percentage of the video field area above a specific density threshold, an accurate representation of the extent of myocardial cell shortening (versus time) could be plotted. An electronic derivative of this extent of shortening would provide the velocity of myocardial cell contraction. The extent and velocity of cell shortening during contraction were recorded on a dual channel strip chart recorder. The electronic circuitry of this system has been explained in more detail in previous publications (27).

Serum was obtained from patients or controls by drawing blood into sterile glass test tubes, the blood was allowed to sit at room temperature $\left(20^{\circ} \mathrm{C}\right)$ for $30 \mathrm{~min}$ and then spun at $1,000 \mathrm{~g}$ for $15 \mathrm{~min}$, and then serum was pipetted in $0.5-\mathrm{ml}$ aliquots into plastic tubes which were frozen at $-70^{\circ} \mathrm{C}$ until assayed. Serum was obtained within $0.5 \mathrm{~h}$ of the cardiovascular evaluation to which it was compared. Initially, assays of myocardial cell extent and velocity of shortening were performed immediately; however, it was found that there was no change in results when comparing assays performed on the same serum samples if the assay was performed within 6 mo of one another (see Table III). Thus the depressant substance appeared to be stable at $-70^{\circ} \mathrm{C}$ for at least $6 \mathrm{mo}$.

To evaluate the effects of a specific serum sample, the test serum was diluted (10\% serum) in a physiologic media consisting of $65 \%$ Dulbecco's BSS-K, and 25\% Medium 199 (28). The culture media was aspirated off

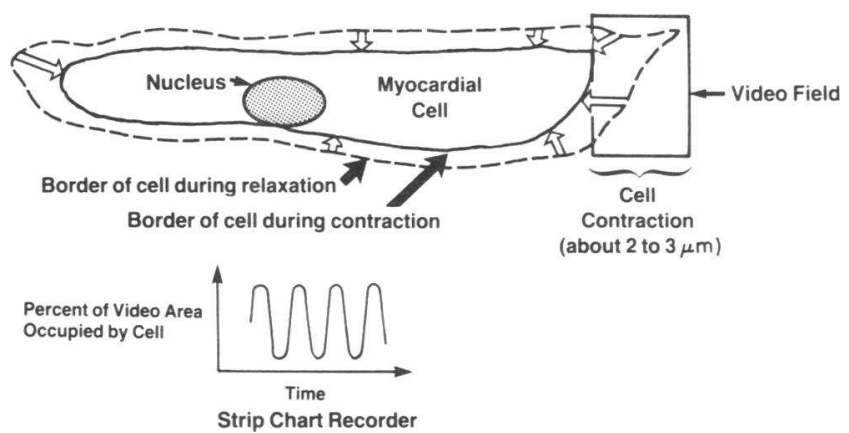

Figure 2. A schematic diagram of the variable area method of detecting cell movement. The beating edge of a cell was placed in the video field. The electronics of this video field measured instantaneously the area within the video field above a specific density threshold. The adjustable density threshold was chosen so that the myocardial cell density was above the measured threshold and all the area around the cell within the video field was below the measured threshold. The output was recorded on a strip chart recorder which displayed the percent of the video field area that was occupied (or not occupied) by the cell at any point in time. For a more detailed explanation, see text. 
the beating heart cells in a petri dish. The media was replaced with $2 \mathrm{ml}$ of physiologic media plus $10 \%$ heat-inactivated newborn calf serum and the cells were allowed to equilibrate for $15 \mathrm{~min}$ on the microscope stage. It should be noted that preliminary experiments demonstrated that the newborn calf serum used in these experiments produced no depression or enhancement when compared to media alone with no serum. Thus, heat-inactivated newborn calf serum in physiologic media was employed as a control media. The extent and velocity of cell shortening with this control media were recorded at a paper speed of 1 and $5 \mathrm{~mm} / \mathrm{s}$. Butterfly needles of 21-gauge size had been placed through the side of the petri dish to allow very slow removal and replacement of media over the cells without mechanically disturbing the cells. The $2 \mathrm{ml}$ of $10 \%$ test serum plus physiological media was then placed over the cells and allowed to equilibrate for $15 \mathrm{~min}$. The extent and velocity of shortening were again recorded on the strip chart at 1 and $5 \mathrm{~mm} / \mathrm{s}$ of paper speed. The media was again changed back to the original control physiologic media (several volumes of control media washed the cells), equilibrated for $15 \mathrm{~min}$, and recorded as previously. In preliminary experiments employing from 1to 60-min incubations, it was documented that no test media took longer than 15 min to produce the maximum effect on myocardial cell contraction; thus, all readings were subsequently performed after $15 \mathrm{~min}$ of incubation. With all of the test sera used in this study, the depression or enhancement of contractility was reversible by replacing the test sera with control sera.

The percent depression or enhancement of myocardial cell performance was calculated employing the following formula: Percent depression or enhancement $=$ (decrease or increase in extent [or velocity] of shortening with test serum)/(extent [or velocity] of shortening with physiologic media and $10 \%$ newborn calf serum).

To determine the extent or velocity of shortening for a test or control sera, 10 beats of a myocardial cell extent and velocity of shortening were measured and averaged. Test serum was initially run in duplicate samples until the reproducibility of samples was always $<10 \%$; then a single determination for each sample was performed. With 10 patients, test serums were repeated on a different day with a different group of heart cells in culture, and the reproducibility of any depression or enhancement was found to be $<10 \%$ (usually $<5 \%$ ) for all these determinations. Thus, the assay demonstrated excellent reproducibility.

Preliminary experiments were performed to determine whether this in vitro assay was responsive to pharmacologic agents that were known to enhance or depress myocardial cell contractility. Table III contains data that is representative of experiments performed to determine the effects of various catecholamines, corticosteroids, serum storage at $-70^{\circ} \mathrm{C}$, verapamil, and calcium concentrations on the in vitro assay of myocardial cell performance. Addition of increasing concentrations of norepinephrine produced a stepwise increase in extent and velocity of shortening of myocardial cells. Dopamine produced a mild increase in myocardial cell performance at the highest concentration tested. Methylprednisolone had no significant effect on myocardial performance in vitro. Storage of a septic shock patient's sera for up to $12 \mathrm{mo}$ at $-70^{\circ} \mathrm{C}$ did not induce any change in the ability of the sera to induce depression of both extent and velocity of shortening during myocardial cell contraction. Increasing concentrations of the calcium channel blocker, verapamil, caused a stepwise decrease in myocardial performance. The electrolytes $\left(\mathrm{Na}, \mathrm{K}, \mathrm{CO}_{2}\right.$, and $\mathrm{Cl}$ ) were all tested within the range seen during these experiments and produced no change in myocardial cell performance (not shown in Table III). Calcium concentrations (Table III) in increasing amounts induced an increase in extent (and to a lesser degree in velocity) of shortening of myocardial cells during contraction. It should be noted that multiple samples of patient sera $(10 \%)$ mixed with physiologic media were tested in this study and all test mixtures had a calcium level of 1.8 $\mathrm{mm} / \mathrm{ml}$ because the $10 \%$ test sera were all diluted by a $90 \%$ media containing $1.8 \mathrm{~mm} / \mathrm{ml}$ of calcium (see below for further explanation).

Effects of rate on myocardial performance in vitro. For several experiments, the beating rate of myocardial cells in vitro was increased by pacing the spontaneously beating cells at a faster than spontaneous rate. A Medtronic 5375 demand pulse generator (Medtronic Inc., Minneapolis, MN) was attached to a 4 French USCI bipolar pacemaker electrode.
The electrode was passed through a hole in the petri dish and put on top of the beating myocardial cell monolayer. Employing a 20-mA output, the cells could be paced at rates up to 120 beats/min.

Statistical evaluation. Comparisons between control and patient groups were performed using the paired or unpaired Student's $t$ test. Spearman coefficients of rank correlation were calculated to evaluate the relationships between the in vitro myocardial cell performance and the in vivo radionuclide-determined EF. A $P$ value of $<0.05$ was considered statistically significant.

\section{Results}

Examples of serum-induced decreases in in vitro myocardial cell performance. Fig. 3 demonstrates several representative examples of the effect of serum from patients during the acute phase of septic shock on the in vitro performance of myocardial cell contraction. Acute-phase shock serum produced substantial decreases in both extent and velocity of shortening during contraction. After the test serum was removed from the cells, the base-line extent and velocity of shortening return.

No test serum reported in this study induced a change of $>30$ beats/min (only two patients changed their rate $>20$ beats/ $\mathrm{min}$ ) in the rate of myocardial cell contraction. There was no consistent pattern of change between the change in rate and the change in performance, i.e., an increase or decrease in rate did not predict a similar change in extent or velocity of shortening.

Comparison of patient and control groups. Fig. 4 illustrates the percent change in extent of myocardial cell shortening induced by $10 \%$ serum obtained from control groups (normal laboratory personnel, patients with a decreased EF secondary to structural heart disease, and critically ill nonseptic controls) and from patients during the acute phase and during the recovery phase or the presepsis phase of their illness. Statistical comparison of the five groups reveals that the septic shock patients during the acute phase had a statistically significantly lower mean \pm standard error of the mean (SEM) percent change in amplitude $(-33.0 \pm 4.0 \%, P<0.001)$ when compared to any of the three control groups $(-1.7 \pm 2.9 \%$ for laboratory personnel, $-1.2 \pm 2.9 \%$ for structural heart disease, and $-0.6 \pm 3.3 \%$ for critically ill nonseptic controls) or when compared to the recovery or presepsis patients $(+11.9+5.0 \%)$. None of the three control groups demonstrated significant differences in extent of shortening. The recovery or presepsis patients had a statistically higher $(+11.9+5.0 \%)$ mean extent of shortening when compared to any of the three control groups $(P<0.05)$.

The mean EF of the structural heart disease patients $(0.288 \pm 0.023)$ and the acute-phase septic shock patients $(0.329 \pm 0.029)$ were both significantly lower $(P<0.001)$ than the critically ill nonseptic controls $(0.564 \pm 0.025)$ and the recovery or presepsis septic shock patients $(0.503 \pm 0.047)$. The mean $\mathrm{EF}$ of the structural heart disease controls was similar to the mean EF of the acute-phase septic shock patients $(P=\mathrm{NS})$. The mean EF of the critically ill septic shock controls was similar to the mean EF of the recovery or presepsis septic shock patients $(P=\mathrm{NS})$.

Fig. 5 illustrates that similar results were seen when analyzing the control and patient groups regarding the effect of serum on the velocity of myocardial cell shortening in vitro. The mean percent decrease $(-24.6 \pm 3.9 \%)$ in myocardial cell velocity of shortening induced by $10 \%$ serum from patients during the acute phase of septic shock was significantly lower $(P<0.001)$ than that induced by laboratory personnel $(+1.9 \pm 3.4 \%)$, controls with 
Table III. Effects of Catecholamines, Corticosteroids, Serum Storage at $-70^{\circ} \mathrm{C}$, Verapamil, and Calcium on In Vitro Myocardial Cell Performance

\begin{tabular}{|c|c|c|c|c|}
\hline Solution tested & Concentration & $\begin{array}{l}\text { \% change in extent of } \\
\text { myocardial cell } \\
\text { shortening }\end{array}$ & $\begin{array}{l}\text { \% change in velocity of } \\
\text { myocardial cell } \\
\text { shortening }\end{array}$ & Rate of contraction \\
\hline & & & & beats/min \\
\hline Culture media* & & - & - & 60 \\
\hline \multicolumn{5}{|l|}{ Culture media $+10 \%$ Heat inactivated } \\
\hline Newborn calf serum $\ddagger$ & & 0 & 0 & 60 \\
\hline \multirow[t]{4}{*}{ Norepinephrine $(\mu g / m l)$} & $10^{-4}$ & +2 & +1 & 62 \\
\hline & $10^{-3}$ & +33 & +16 & 64 \\
\hline & $10^{-2}$ & +44 & +28 & 64 \\
\hline & $10^{-1}$ & Beating stopped & - & - \\
\hline \multirow[t]{4}{*}{ Dopamine $(\mu g / m l)$} & $10^{-4}$ & +5 & +4 & 62 \\
\hline & $10^{-3}$ & +2 & +2 & 62 \\
\hline & $10^{-2}$ & -2 & +2 & 62 \\
\hline & $10^{-1}$ & +11 & +8 & 60 \\
\hline \multirow[t]{3}{*}{ Methylprednisolone $(\mu \mathrm{g} / \mathrm{ml})$} & $10^{-1}$ & 0 & 0 & 64 \\
\hline & 1 & 0 & 0 & 64 \\
\hline & 10 & 0 & 0 & 64 \\
\hline $\begin{array}{l}\text { Serum, } 10 \% \text {, from septic shock } \\
\text { patient }\end{array}$ & - & -40 & -32 & 62 \\
\hline \multicolumn{5}{|l|}{ Serum frozen at $-70^{\circ} \mathrm{C}$ and tested @ } \\
\hline $2 \mathrm{mo}$ & - & -38 & -32 & 60 \\
\hline $4 \mathrm{mo}$ & - & -44 & -30 & 57 \\
\hline $8 \mathrm{mo}$ & - & -35 & -28 & 61 \\
\hline $12 \mathrm{mo}$ & - & -41 & -34 & 58 \\
\hline \multirow[t]{3}{*}{ Verapamil $(\mu g / m l)$} & $10^{-2}$ & -8 & -15 & 60 \\
\hline & $10^{-1}$ & -16 & -14 & 58 \\
\hline & 1 & -44 & -38 & 58 \\
\hline Calcium (control media for this & 0.9 & +7 & +8 & 60 \\
\hline experiment contained trace & 1.8 & +36 & +11 & 58 \\
\hline amounts of calcium), $(\mathrm{mm} / \mathrm{ml})$ & 3.6 & +43 & +11 & 58 \\
\hline
\end{tabular}

Norepinephrine (Breon Laboratories, New York); dopamine (Abbott Laboratories, North Chicago, IL); methylprednisolone (Upjohn Labs, Kalamazoo, MI); verapamil (Isoptin from Knoll Labs, Whippany, NJ). * For the solutions that constitute culture media, see Methods. $\ddagger$ For processing of heat-inactivated newborn calf sera, see Methods.

structural heart disease $(+3.8 \pm 3.5 \%)$, critically ill controls $(-0.3 \pm 3.2 \%)$, or septic shock patients during the recovery or presepsis phase $(+12.4 \pm 6 \%)$. The percent change in velocity of shortening in the three control groups and the septic shock patients during the recovery or presepsis phase was similar ( $P=$ NS comparing any two of these groups).

Comparison of survivors and nonsurvivors. There was no statistically significant different between the in vitro extent or velocity of shortening demonstrated by the survivors versus the nonsurvivors in any of the control groups or patient groups.

Comparison of acute- and recovery-phase EFs, extent, and velocities of shortening. Fig. 6 provides a comparison of the effects of serum on myocardial cell extent and velocity of shortening compared with radionuclide EF during both the acute and recovery (or presepsis) phases of septic shock in 11 septic shock patients. In these 11 patients, the EF rose from (mean \pm SEM) $0.283 \pm 0.041$ during the acute phase to $0.503 \pm 0.047$ during the recovery or presepsis phase; the percent change in extent of shortening rose from $-37.9 \pm 4.9 \%$ to $11.9 \pm 5.0 \%$; the percent change in myocardial cell velocity of shortening rose from $-26.6 \pm 5.0 \%$ to $+12.4 \pm 6.4 \%$. All of these increases were highly statistically significant $(P<0.001$ comparing acute to recovery or presepsis phases of EF, amplitude, or velocity). All 11 patients demonstrated simultaneous increases in EFs, extent of myocardial cell shortening, and velocity of myocardial cell shortening while going from the acute to the recovery or presepsis phase of septic shock. If only nine patients (excluding the two patients who were nonsurvivors and had presepsis rather than recovery data) were used in the acute- and recovery-phase analysis, all of the statistical analyses remain highly statistically significantly different and were identical to those comparisons with 11 patients.

Comparison of acute- and recovery-phase cardiovascular parameters other than $E F$. In addition to $\mathrm{EFs}$, other cardiovascular parameters that could be determined from thermodilution cardiac indices, e.g., SVI, or calculated from radionuclide EF and thermodilution cardiac index, e.g., end diastolic volume index, were analyzed. These cardiovascular functional parameters were compared during the acute and recovery phases, and also compared to the in vitro amplitude and velocity of myocardial cell contraction.

In the 11 septic shock patients with acute and recovery $(n=9)$ or presepsis $(n=2)$ cardiovascular evaluations, in contrast to the EF which increased toward normal in every patient (see 


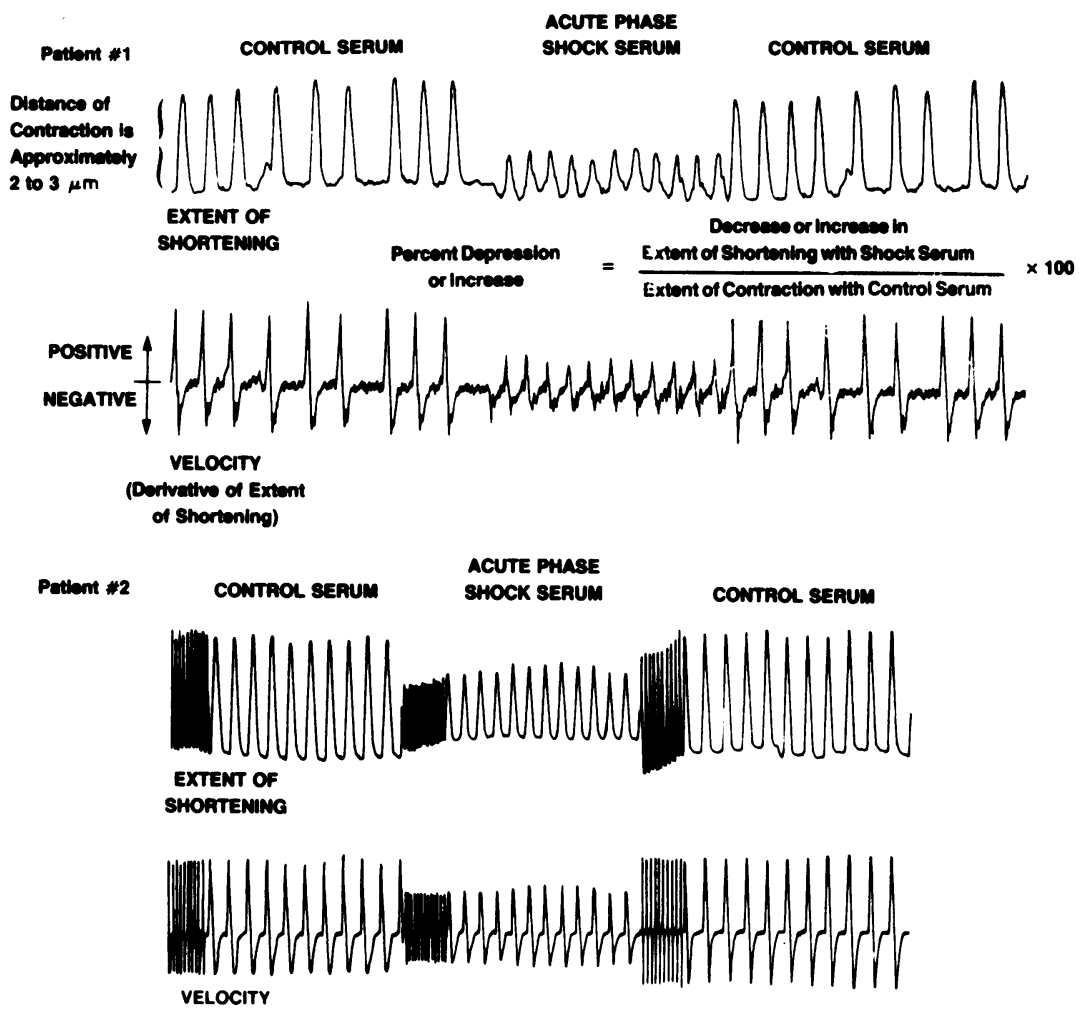

Pationt *3 COMTrol senum ACUTE PHASE
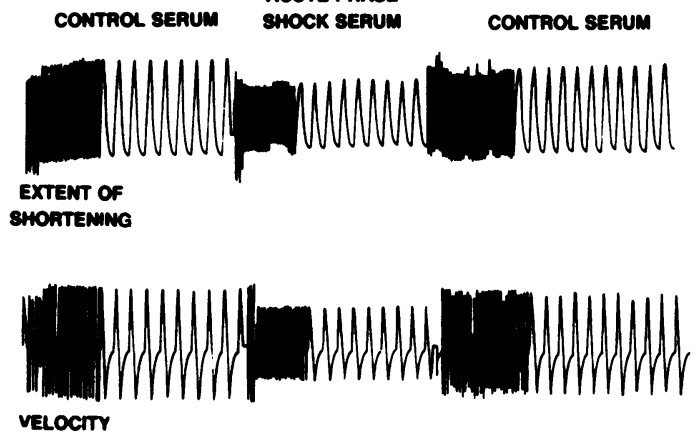

Figure 3. Representative examples of the effect of serum from three different patients during the acute phase of septic shock. For each patient, the upper panel displays the extent of shortening and the lower panel displays velocity of shortening without shock serum. A mixture of $10 \%$ shock serum and $90 \%$ physiologic media was added to the cells in the petri dish and allowed to incubate for $15 \mathrm{~min}$ at $37^{\circ} \mathrm{C}$ and a recording was made; then the $10 \%$ shock serum/ media mixture was removed, the dish was washed and replaced with several volumes of media plus $10 \%$ control serum (newborn calf). After $15 \mathrm{~min}$ of incubation, another recording was made. The formula employed for calculating the percent depression is shown in the diagram. For each patient, 10 consecutive beats were averaged to produce one mean value. For more detail, see text.
Figure 4. The effect of serum from control and patient groups on the extent of myocardial cell shortening of spontaneously beating rat heart cells in vitro. (O) Patients who survived; (๑) patients who did not survive the acute illness. The mean for each group is shown by a horizontal line. Septic shock patients during the acute phase demonstrated a statistically significantly lower extent of shortening $(P<0.001)$ compared to any other control or patient group. See text for details. 


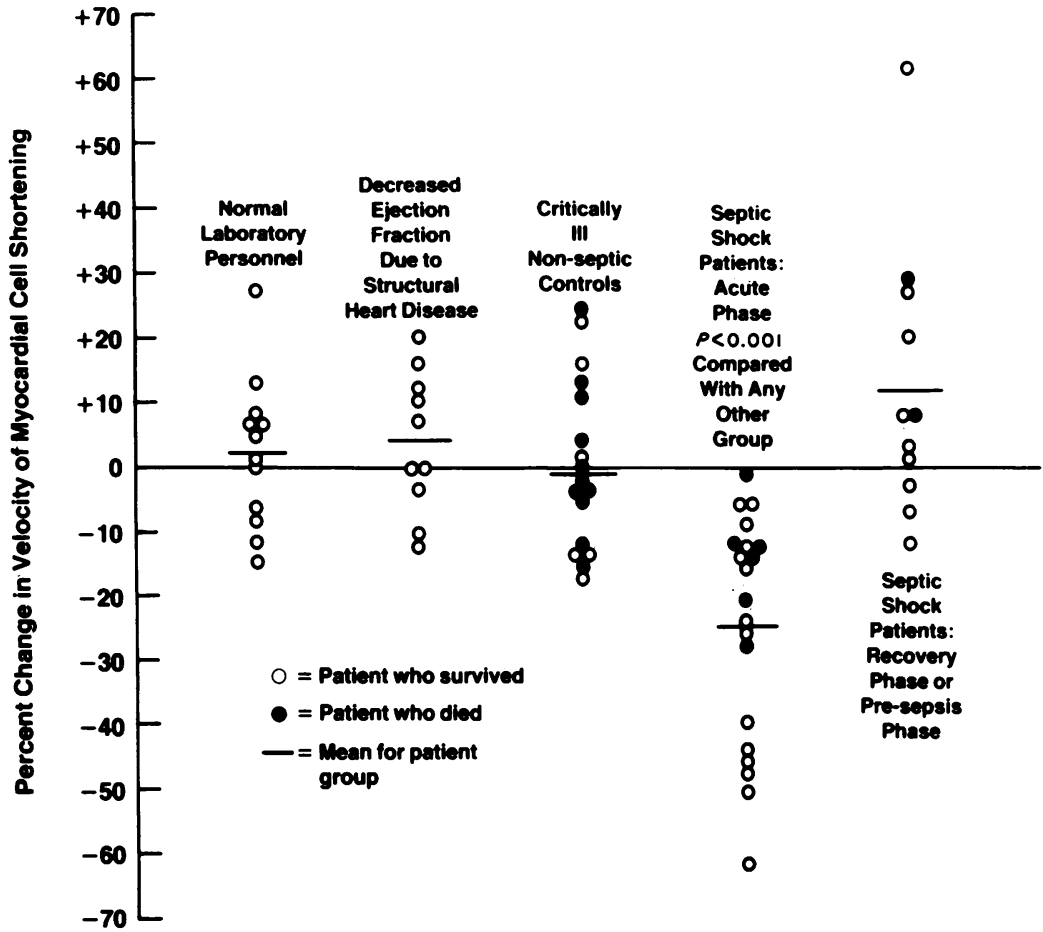

Figure 5. The effect of serum from control and patient groups on the velocity of shortening of spontaneously beating rat heart cells in vitro. Symbols, mean bars, and statistics are the same as in Fig. 4.
Fig. 6), the cardiac index changes were variable: five patients increased, five patients decreased, and one patient was unchanged. Similar variable changes were evident in stroke volume index. In these same 11 patients, the end diastolic volume index decreased toward normal in 10 patients, the only exception was in a nonsurvivor (patient $\mathrm{P} 11$ in Table $\mathrm{I}$ ).

It should be noted that of the 20 septic shock patients (Table I), 17 patients are identical with those reported in a previous study (17). For an analysis of the transient reversible changes in $\mathrm{EF}$, cardiac index, stroke volume index, systemic vascular resistance index, and end diastolic volume index, evident in septic shock patients, the reader is referred to this previous study.

Correlation of EF with the extent of myocardial cell shortening. Fig. 7 illustrates the relationship between the radionuclidedetermined in vivo left ventricular EF and the in vitro percent change in extent of myocardial cell shortening in the 20 septic shock patients during the acute phase. Using the Spearman rank method, there was a statistically significant positive correlation between these two variables with an $r$ value of +0.52 and a $P<0.01$. Although a positive correlation was noted $(r=+0.19)$ between EF and myocardial cell velocity of shortening (no illustration), this relationship lacked statistical significance $(P=\mathrm{NS})$.

As with EFs, Spearman rank correlations were performed between cardiac index, stroke volume index, and end diastolic volume index versus in vitro myocardial cell amplitude and velocity. No significant correlations were found between cardiac index or stroke volume index and any in vitro parameter. However, in the 20 acute-phase septic shock patients, the end diastolic volume index demonstrated a significant negative correlation ( $r=-0.41, P<0.05$ ) with the extent of myocardial cell shortening; no significant correlation was seen with velocity.

Evaluation of other parameters that could potentially affect myocardial cell performance. As mentioned in Methods, all of the patients and controls in this study had frequent (every 4-6 h) measures of blood $\mathrm{pH}, \mathrm{PCO}_{2}$, sodium, potassium, carbon dioxide, chloride, calcium, phosphate, magnesium, and glucose. All these electrolytes and metabolites were kept in the normal range. Because the myocardial contractility assay was performed on $10 \%$ test serum plus $90 \%$ physiologic media, the latter would tend to correct any abnormality due to electrolyte differences. We measured the $10 \%$ serum and media mixture for concentrations of $\mathrm{Na}, \mathrm{K}, \mathrm{Ca}, \mathrm{PO}_{4}, \mathrm{Mg}$, and serum $\mathrm{pH}$ on 10 septic shock sera that produced depressions in myocardial extent of shortening and compared them to 10 sera and media mixture from 10 critically ill nonseptic patients. The electrolyte concentrations were essentially identical in these two groups. We concluded that electrolyte differences could not account for the differences in myocardial performance in vitro.

We analyzed the pharmacologic therapy of the patients and controls. Particular attention was paid to any pharmacologic agent that was felt to potentially affect cardiac function. No patient in this study was receiving digitalis, beta-blocking agents, or calcium channel-blocking agents. No serum was obtained within $3 \mathrm{~h}$ of a large dose of corticosteroids.

As mentioned in Methods, all these patients were treated by one group of critical care physicians according to a sequential protocol that began with fluid administration to increase the pulmonary capillary wedge pressure to $15 \mathrm{mmHg}$. The pulmonary capillary wedge pressure was very similar in the 20 acutephase septic shock patients (mean $=12.5 \mathrm{mmHg}$ ) and the 17 critically ill nonseptic control patients (mean $=13.2 \mathrm{mmHg}$, $P=\mathrm{NS}$ ). If one employed the end diastolic volume index as a measure of preload (some authors would argue that end diastolic volume is a better measure of preload than pulmonary capillary wedge pressure [18]), the acute-phase septic shock patients have a higher end diastolic volume than the critically ill nonseptic controls but they have a decreased ventricular performance despite a higher preload. We concluded that differences in preload cannot account for the differences between patients and controls.

Some patients were receiving the vasopressor agents dopamine and/or levarterenol. However, the septic shock patients 

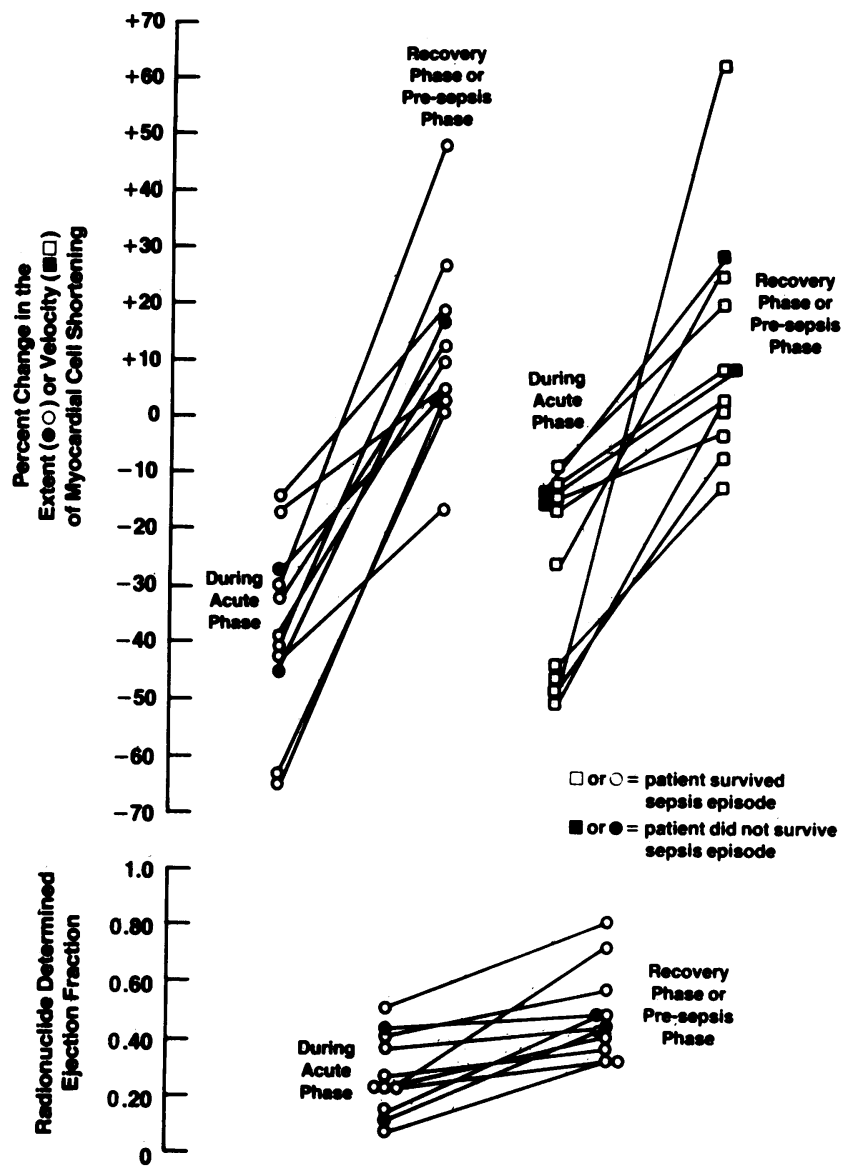

Figure 6. A comparison of the effects of serum on the extent (upper panel, circles) and velocity (upper panel, boxes) of myocardial cell shortening compared with radionuclide-determined EF (lower panel, circles) in 11 patients both during the acute and recovery $(n=9)$ or presepsis $(n=2)$ phases of septic shock. $(0, \square)$ Patients who survived; $(\bullet, \varpi)$ patients who were nonsurvivors. The lines connect the acute and recovery or sepsis phases for each patient. In all 11 patients, the transition from acute phase to recovery $(n=9)$ or presepsis $(n=2)$ phase was characterized by an increase in the in vivo $\mathrm{EF}$ and an increase in the in vitro measures of extent and velocity of myocardial cell shortening.

during the acute phase demonstrated significant decreases in myocardial cell extent and velocity of shortening during contraction, yet these patients were receiving dopamine and norepinephrine, agents which enhanced contractility when tested in vitro (Table III). Thus, the findings in this study were contradictory to what one would predict if catecholamine infusions were accounting for our findings. One could argue that even greater in vitro depressions might be evidenced if catecholamines were not in the serum tested. Further, 8 of the 20 septic shock patients during the acute phase were not receiving exogenous dopamine or norepinephrine and these 8 patients had depressions similar to those of the 12 receiving infusions. Conversely, some nonseptic critically ill controls were receiving dopamine or levarterenol and none developed decreases in in vitro myocardial cell performance. In addition, employing Spearman rank coefficients in the acute-phase septic shock patients, no correlation was found between changes in myocardial extent or velocity of shortening and doses of dopamine or norepinephrine. Thus, we conclude that vasopressor administration cannot account for the findings reported in this study.
The relationship between mechanical ventilation or the amount of positive end expiratory pressure versus the EF and the in vitro myocardial cell performance was investigated. In the 20 acute-phase septic shock patients, the 12 patients on mechanical ventilation had similar EFs and myocardial cell performance in vitro when compared to nonmechanically ventilated patients. In this group, patients on significant levels of positive end expiratory pressure $\left(>5 \mathrm{cmH}_{2} \mathrm{O}\right)$ also had similar EFs and myocardial cell performance in vitro when compared to patients on $<5 \mathrm{~cm}$ or no positive end expiratory pressure. Several critically ill nonseptic patients were on mechanical ventilation and/or on positive end expiratory pressure and none demonstrated a decreased EF or a depressed in vitro myocardial cell performance. Thus, mechanical ventilation or positive end expiratory pressure could not account for the findings reported in this study.

Analysis of serial cardiovascular studies and serial in vitro myocardial cell performance studies in nonsurviving patients. As shown in Fig. 6, septic shock patients who survived would increase their EF toward normal, and the extent and velocity of in vitro myocardial cell performance increased toward control levels. One theory of myocardial dysfunction in septic shock (12-14) argued that nonsurvivors of septic shock would develop a myocardial depressant factor-induced progressive decrease in cardiac index during the late stage of the disease ultimately culminating in a low cardiac index-induced death. Of the 20 septic shock patients reported in this study (Table I), six were nonsurvivors. One of these six, P10 (see Table I), demonstrated a progressive decrease in both EF and cardiac index over an 11-d illness with a concomitant decrease in serum-induced depression of myocardial cell amplitude (from $+17 \%$ to $-41 \%$ ) and velocity. However, five of the six nonsurviving patients demonstrated no significant changes in cardiac index or EF over a 2-10-d (mean $=5 \mathrm{~d}$ ) illness, and serum-induced depression of myocardial cell extent of shortening (from $-17 \%$ to $-17 \%$ ) and velocity of shortening did not change as the patients approached their demise.

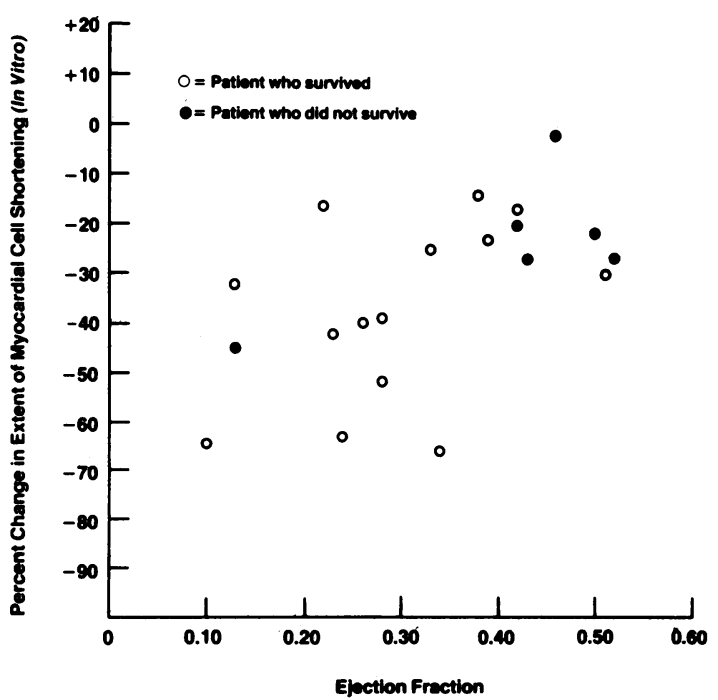

Figure 7. Correlation of radionuclide-determined left ventricular EF and the extent of myocardial cell shortening in vitro in patients during the acute phase of septic shock. Spearman rank correlation revealed an $r=+0.52$ and $P<0.01$. ( $(0)$ Surviving patients; ( $(\bullet)$ nonsurviving patients. Most nonsurvivors demonstrated an EF $>0.40$. See text for details. 


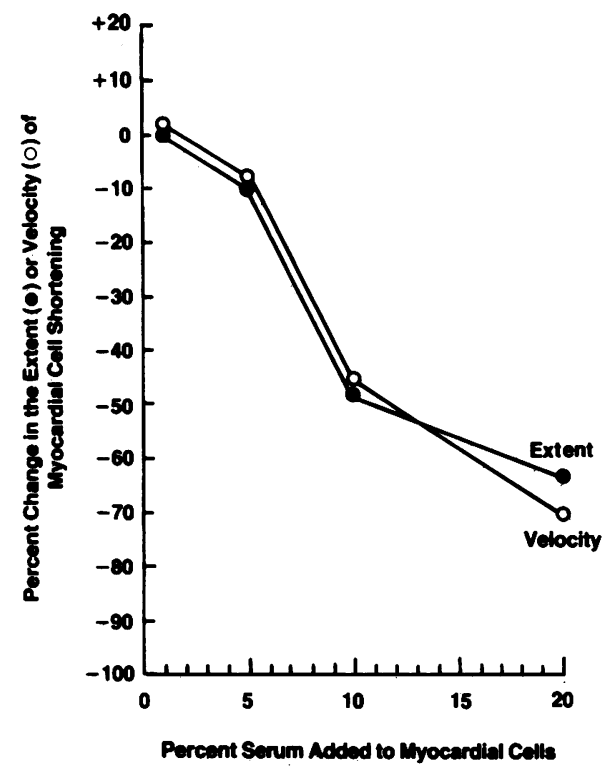

Figure 8 . The effect of increasing the percentage of serum in the serum/media mixture on the extent $(\bullet)$ and velocity $(0)$ of myocardial cell shortening using serum from a patient during the acute phase of septic shock. The serum concentrations of $1,5,10$, and $20 \%$ were used and resulted in a stepwise decrease in extent and velocity of shortening. Please see text for further details.

Dose response of depressant serum. Fig. 8 demonstrates the dose-response characteristics of serum from a representative patient (P4) during the acute phase of septic shock. Increasing the amount of depressant serum in the media applied to the beating myocardial cells resulted in a stepwise decrease in both the extent and velocity of shortening during myocardial cell contraction. This dose-response capability was demonstrable with any serum containing depressant activity.

Analysis of the effect of myocardial cell beating rate on extent and velocity of myocardial cell shortening. Table IV summarizes an experiment to evaluate the effect of myocardial cell rate on myocardial cell performance. Employing an exogenous pacemaker, the myocardial cell monolayer beating rate was increased from 30 to as high as 72 beats/min without any increase or decrease in extent or velocity of myocardial cell shortening. Shock sera $(10 \%)$ induced a decrease in extent $(-36 \%)$ and velocity $(-15 \%)$ of myocardial cell shortening at a spontaneous beating rate of $30 / \mathrm{min}$. When the beating rate was increased to $48 / \mathrm{min}$ by the pacemaker, no significant change in extent or velocity of myocardial cell shortening was produced. Thus, changes in beating rate did not affect myocardial performance in vitro.

Experiments performed to characterize the molecular size and solubility characteristics of myocardial depressant substance. Tables V and VI summarize a series of experiments performed to characterize the size and solubility characteristics of the circulating depressant substance. Patient serum obtained during the acute phase of septic shock and containing depressant activity was placed in cellophane dialysis bags and dialyzed against a 1,000-ml bath of $20 \mathrm{~mm}$ of phosphate-buffered saline (PBS) with $\mathrm{pH}$ of 7.40 at $4^{\circ} \mathrm{C}$. The bath was replaced with fresh PBS every $12 \mathrm{~h}$ for a 48-h period. As controls, patient shock serum was kept in the same $4^{\circ} \mathrm{C}$ cold room for $48 \mathrm{~h}$. Dialyzed serum lost its depressant activity, whereas control nondialyzed serum retained the ability to depress extent and velocity of heart cell shortening. Thus, myocardial depressant substance can diffuse through a dialysis membrane. In general, molecules with a mol wt 10,000 or less can pass through this type of membrane. Thus, myocardial depressant substance probably has a mol wt $<10,000$. Although Table $\mathrm{V}$ contains data from two patients, this dialysis equipment has been performed on four shock patients with similar results to those shown.

Table $\mathrm{V} B$ demonstrates representative experimental results from serum of patients with septic shock passed through Amicon filters (Amicon Corp., Danvers, MA), filters designed to separate molecules on the basis of molecular size. Employing membranes that allow passage of molecules with $\mathrm{mol} \mathrm{wt}<10,000$ (Amicon filter PM10) or $<5,000$ (Amicon filter YM5) demonstrate that depressant activity is clearly contained in the group with mol wt $<5,000$. Employing a membrane (Amicon YC05) that allows passage of only small molecules ( $<500 \mathrm{~mol} \mathrm{wt}$ ), the activity is retained in the residual $(>500 \mathrm{~mol} \mathrm{wt})$ fraction (Table $\mathrm{V} \mathrm{B3}$ ). Because salt, catecholamines, and most pharmacologic agents are found in the fraction with a mol wt $<500$, this experiment provides strong data against these substances accounting for de-

Table IV. Effect of Pacemaker-induced Changes in Cellular Beating Rate on the Extent and Velocity of Myocardial Cell Performance In Vitro

\begin{tabular}{|c|c|c|c|c|}
\hline Solution bathing myocardial cells & Pacemaker rate* & $\begin{array}{l}\text { Myocardial cell } \\
\text { rate of contraction }\end{array}$ & $\begin{array}{l}\text { \% change in extent of } \\
\text { myocardial cell } \\
\text { shortening }\end{array}$ & $\begin{array}{l}\text { \% change in velocity of } \\
\text { myocardial cell } \\
\text { shortening }\end{array}$ \\
\hline Culture media & Off & 30 & - & - \\
\hline \multirow[t]{5}{*}{ Culture media $+10 \%$ newborn calf serum } & Off & 30 & $\mathbf{0}$ & 0 \\
\hline & 100 & 60 & 0 & 0 \\
\hline & Off & 30 & 0 & 0 \\
\hline & 120 & 72 & 0 & 0 \\
\hline & Off & 30 & $-\ddagger$ & $-\ddagger$ \\
\hline \multirow[t]{3}{*}{ Culture media $+10 \%$ shock serum } & Off & 39 & -36 & -15 \\
\hline & 48 & 48 & -36 & -13 \\
\hline & Off & 32 & -34 & -13 \\
\hline
\end{tabular}

* A Medtronic 5375 demand pulse generator was attached to a 4 French bipolar USCI pacemaker electrode that was placed into the petri dish containing myocardial cells growing as a monolayer on the bottom of the dish. A 20-mA output with rates from 30 to 120 beats/min was used. $¥$ This experiment is a base-line study i.e., a different myocardial cell is being used and subsequent experiments will be compared to this base line. 
Table V. Experiments Performed to Characterize the Molecular Size and Solubility of Myocardial Depressant Substance

\begin{tabular}{lll}
\hline & $\begin{array}{l}\text { \% change in } \\
\text { extent of } \\
\text { myocardial cell } \\
\text { shortening }\end{array}$ & $\begin{array}{l}\text { \% change in } \\
\text { velocity of } \\
\text { myocardial cell } \\
\text { shortening }\end{array}$ \\
\hline
\end{tabular}

A. Dialysis through cellophane dialysis bags*

\begin{tabular}{|c|c|c|}
\hline $\left.\begin{array}{l}\text { HA1 } \\
\text { BE1 }\end{array}\right\}$ Pretreatment & $\begin{array}{l}-41 \\
-23\end{array}$ & $\begin{array}{l}-23 \\
-29\end{array}$ \\
\hline HA l)Kept at $40^{\circ} \mathrm{C}$ for & -39 & -25 \\
\hline BE1 $\int 48 h$ & -25 & -31 \\
\hline HA1)Dialyzed against & -1 & +2 \\
\hline BE1 $\int$ PBS for $48 \mathrm{~h}$ & -6 & -5 \\
\hline
\end{tabular}

B. Amicon filtration‡

1. Filter PM10: Molecules of mol/wt $<10,000$ pass through filter

HA1 $\left\{\begin{array}{lrr}\text { Prefilter } & -48 & -22 \\ \text { Filtrate }(<10,000) \S & -42 & -28 \\ \text { Residual }(>10,000) & -3 & +1\end{array}\right.$
HA2 $\left\{\begin{array}{lrr}\text { Prefilter } & -28 & -19 \\ \text { Filtrate }(<10,000) & -30 & -19 \\ \text { Residual }(>10,000) & +6 & 0\end{array}\right.$

2. Filter YM10: Molecules of mol wt $<5,000$ pass through filter

BR1 $\left\{\begin{array}{lrr}\text { Prefilter } & -33 & -21 \\ \text { Filtrate }(<5,000) & -39 & -26 \\ \text { Residual }(>5,000) & 0 & +1\end{array}\right.$
HA2 $\left\{\begin{array}{lrr}\text { Prefilter } & -48 & -18 \\ \text { Filtrate }(<5,000) & -52 & -21 \\ \text { Residual }(>5,000) & -2 & +3 .\end{array}\right.$

3. Filter YCO5: Molecules of mol wt $<500$ pass through filter

\begin{tabular}{|c|c|c|c|}
\hline & Prefilter & -48 & -31 \\
\hline & Filtrate $(<500)$ & +1 & +4 \\
\hline & Residual (>500) & -53 & -23 \\
\hline \multirow{3}{*}{ JP2 } & Prefilter & -21 & -16 \\
\hline & Filtrate $(<500)$ & ND" & ND \\
\hline & Residual (>500) & -28 & -15 \\
\hline
\end{tabular}

C. Differential solubility (ethylacetate)

HAl $\left\{\begin{array}{lrr}\text { Pre-processing } & -36 & -38 \\ \text { Aqueous phase } & -37 & -38 \\ \text { Organic phase } & 0 & -3\end{array}\right.$

* In general, molecules of mol wt $<10,000$ will pass through cellophane dialysis bags.

‡ Diaflow ultrafiltration membranes, Amicon Corp., Danvers, MA. § Filtrate and residual are brought up in a volume comparable to the prefiltration yolume so relative potency measurements can be made. "ND, not done.

pressant activity. Based on these filtration experiments, the myocardial depressant substance probably has a mol wt between 500 and 5000.

The solubility of myocardial depressant substance was evaluated by employing ethylacetate, an organic solvent (Table V $C)$. After passing serum with known depressant activity through a PM10 filter to exclude the nondepressant fraction with mol $w t>10,000$, the filtrate was lyophilized, dissolved in $1 \mathrm{ml}$ of distilled water, mixed with $1 \mathrm{ml}$ of ethylacetate, thoroughly mixed, and allowed to separate into aqueous and organic phases. The aqueous phase was lyophilized, and the organic phase was evaporated under nitrogen. As shown in Table V, all the activity was retained in the aqueous phase. This argues for a water-soluble depressant substance, e.g., a protein or carbohydrate or a combination of these two, and makes an organic soluble substance, e.g., fatlike substances such as prostaglandins or leukotrienes, very unlikely.

Table VI demonstrates a representative gel filtration with G-25 Sephadex, using serum with depressant activity obtained from a patient during the acute phase of septic shock. Similar patterns of G-25 isolation have been seen with four other septic shock patients (not shown). As seen in Table VI, depressant activity was found in fractions 15 and 16 and no other fraction demonstrated significant enhancement or depression (in a single experiment, a decrease or increase of $20 \%$ or more is considered definitely significant). Using the known protein markers, the molecular weight of myocardial depressant substance is between the $\alpha$-chain insulin (mol wt 2,530) and vitamin $\mathrm{B}_{12}$ (mol wt $1,355)$. This finding confirms the Amicon filteration range of $500-5,000 \mathrm{~mol} w t$, and narrows the probable mol wt to $\sim 2,000$.

\section{Discussion}

This study demonstrates that septic shock patients have a circulating myocardial depressant substance in their blood during the acute phase of septic shock. This substance has been shown to decrease the extent and velocity of shortening during myo-

Table VI. G-25 Sephadex Column Chromatography to Evaluate the Size of Myocardial Depressant Substance*

\begin{tabular}{lccc}
\hline Fraction no. $\begin{array}{l}\text { \% change in } \\
\text { extent of } \\
\text { myocardial cell } \\
\text { shortening }\end{array}$ & $\begin{array}{l}\text { \% change in } \\
\text { velocity of } \\
\text { myocardial cell } \\
\text { shortening }\end{array}$ & Known protein markers \\
\hline $1-9$ & 0 & +2 & \\
10 & 0 & 0 & Insulin, beta chain \\
11 & 0 & 0 & (mol wt 3,496) \\
12 & +4 & +6 & Insulin, alpha chain \\
(mol wt 2,530) \\
13 & +3 & 0 & \\
14 & & & \\
15 & -42 & -33 & \\
16 & -32 & -35 & \\
17 & +2 & 0 & \\
18 & 0 & 0 & \\
19 & 0 & 0 & \\
20 & 0 & 0 & \\
21 & 0 & +5 & \\
22 & +9 & -4 &
\end{tabular}

* Column is $60 \mathrm{~cm}$ long and has $1-\mathrm{ml}$ fraction.

¥ By conductivity measurements and direct measurement of sodium, chloride, etc., salt elutes off this column in fractions 20-36. 
cardial cell contraction in an in vitro model of myocardial cell performance. Importantly, this depressant activity has been shown to be absent from serum obtained from normal laboratory personnel, from patients with reduced EFs due to structural heart disease, and from critically ill but nonseptic patients. Employing serial blood sampling and serial measures of cardiovascular function, this depressant activity has been shown to be present during the acute phase of septic shock but to be absent from recovery serum or from presepsis serum. During the acute phase of septic shock, the decreased EF and the increased end diastolic volume index (but not cardiac index or stroke volume index) significantly correlated with the depression in the extent of myocardial cell shortening in vitro. This correlation suggested that the amount of decrease in the extent of myocardial cell shortening in vitro was reflecting the pathophysiologic events responsible for myocardial depression during the acute phase of septic shock in vivo.

Previous studies have described a myocardial depressant factor in various forms of shock (29-38). However, these studies have been significantly flawed due to a variety of reasons, and a chapter reviewing our current understanding of shock in a recent major textbook of medicine (39) termed the presence and role of myocardial depressant factors as "controversial." Many of the previous studies did not include appropriate control groups, i.e., the studies did not demonstrate that depressant activity was absent from normals and absent from other critically ill patients who were not in shock. Other studies did not clearly demonstrate that exogenous medication or electrolyte abnormalities were not responsible for the myocardial depression. Critical investigators have noted that a high salt concentration probably accounted for cardiac depressant activity in a number of experimental systems (40). Most of these previous studies have employed the canine hemorrhagic shock model, a model that is not clearly analogous to any form of human shock.

In addition, none of these studies have clearly related the presence of in vitro myocardial depression (usually employing a papillary muscle or Langendorf isolated heart preparation) to clear-cut cardiac depression in vivo. This relationship is very important and must be proven to exist in order to relate an in vitro phenomenon to the pathophysiologic mechanisms responsible for myocardial depression during shock in patients. Thus, in the present study, we have demonstrated the existence of a myocardial depressant substance in the blood of human septic shock patients early in their course, and quantitatively and temporally related the presense of this depressant activity to concomitant evidence of myocardial dysfunction as demonstrated by a decreased EF and left ventricular dilatation.

The relationship of this circulating myocardial depressant substance to the complex pathogenesis of the human septic shock syndrome is an important but only partially understood phenomena. The cardiovascular abnormalities characteristic of the human septic shock include both cardiac dysfunction and a peripheral vascular abnormality (41). There is also evidence that the initial or early cardiovascular hemodynamic pattern may differ substantially from the hemodynamic abnormalities characteristic of the late phase of septic shock, especially the late phase in nonsurvivors (42). Most of the data reported in this study reflects the early stages of the septic shock syndrome, a time characterized by a high or normal cardiac index, a decreased peripheral systemic vascular resistance, and, as recently demonstrated (17), a decreased EF. Employing volume infusions in septic shock patients, two recent studies $(43,44)$ confirmed the presence of severe reversible myocardial dysfunction in the early phase of human septic shock. Thus, three studies have demonstrated evidence of in vivo myocardial dysfunction early in human septic shock, and the present study has provided evidence that in vitro myocardial depressant activity was clearly present during these initial few days in a large subpopulation of patients with septic shock.

Because patients during the early stages of septic shock have evidence of tissue ischemia with elevation of circulating lactic acid, one possible role of myocardial depressant substance would be to reduce cardiac output resulting in a less than maximal output for any particular patient. This could well contribute to peripheral tissue ischemia. This effect is probably not the major mechanism of tissue ischemia in that the cardiac index and stroke volume are normal or elevated in early septic shock; however, it may be a contributing factor. Maldistribution of peripheral blood flow probably accounts for most of the tissue ischemia (10-14). In one nonsurviving patient in this study (patient P10 in Table I), there were multiple serial measures of both cardiovascular function and myocardial depressant activity until the day of death. In this patient, myocardial depressant activity persisted in the serum until death, and the patient demonstrated serial decreases in cardiac indices and EFs that resulted in a low output syndrome and patient demise. The pattern in this one nonsurvivor suggested that myocardial depressant substance may occasionally cause severe myocardial dysfunction that becomes incompatible with life. However, this pattern is probably not common-most nonsurvivors (or survivors) do not develop a late decrease in either EF or cardiac index. Myocardial depressant activity has not been measured in enough patients to warrant generalizations regarding characteristic serial patterns.

The in vitro myocardial cell contractility assay employed in this study represented a modification of previously described cell culture methods $(21-28)$. These models have been shown to develop spontaneous beating rates and the cells respond to pharmacologic and physiologic agents with appropriate changes e.g., increases or decreases in beating rate or cell inotropy. The latter is usually measured as an increase or decrease in the extent and/or velocity of shortening of a cultured heart cell. Electrolytes, catecholamines, thyroid hormones, and pharmacologic agents have produced appropriate changes in heart cell performance in vitro. As documented in Table III, the myocardial contractility model employed in the present studies responded appropriately to a wide variety of electrolytes and pharmacologic agents. Serum from control or septic patients produced little or only modest changes in beating rate, and the changes in rate were not correlated with changes in cell performance, i.e., extent or velocity of myocardial cell shortening.

Several methods were employed to exclude the possibility that the myocardial depression resulted from salt, electrolytes, pharmacologic agents, or other unsuspected substance. Several control groups were employed. The control group with structural heart disease excluded the possibility that all patients with decreased EFs produced a substance that decreased myocardial cell performance. The control group of critically ill nonseptic patients was included to exclude the possibility that all critically ill patients produce a "toxic" substance that could depress myocardial cell performance. This latter control group included several patients with hypovolemic shock $(n=3)$, cardiogenic shock $(n=1)$, and severe pericardial tamponade $(n=1)$. None of these nonseptic causes of shock were associated with a circulating myocardial depressant substance. Thus, unlike some canine 
models of hypovolemic (hemorrhagic) or cardiogenic shock, humans with these nonseptic causes of shock did not show evidence of a circulating myocardial cell depressant substance.

Another group of patients that provided a superb control comparison was the patients who recovered $(n=9)$ or had a presepsis $(n=2)$ blood sampling and ventricular performance studies. Serum obtained from these 11 patients during the acute phase of septic shock had clear evidence of depressed EF in vivo and a decreased myocardial cell performance in vitro; however, during the recovery phase of presepsis phase, these same patients had returned to normal or mildly enhanced in vitro myocardial cell performance. Thus, the myocardial depressant substance could be produced by a septic shock patient within a few hours (the earliest evidence of in vitro depression was obtained $2 \mathrm{~h}$ after the onset of septic shock), and the substance could be cleared from the serum within 2-3 d.

In addition to using several control groups, we have directly assayed the electrolyte concentrations in the serum/media mixture bathing the myocardial cells and found no differences in electrolyte concentrations between depressant and nondepressant serum/media mixtures. As judged by dialysis, Amicon filtration, and G-25 gel filtration, the molecular weight of the depressant substance $(\sim 2,000)$ was in a range inconsistent with any electrolyte, catecholamine, or other exogenous pharmacologic agent.

In recent years, a number of serum substances with potential physiologic capabilities have been described. A recent study (45) characterized a serum factor that was capable of causing increased release of amino acids from skeletal muscle cells grown in vitro. Serum from patients with sepsis or trauma (clinical syndromes known to be associated with severe proteolysis and catabolism) demonstrated the most potent capability to induce release of amino acids. Previous studies $(35,36)$ of cultured rat myocardial cells have shown that sera from patients with sepsis could inhibit isoproterenol-induced increases in beating rate. The relationship of the depressant substance described in this study to those cited above will require further study.

The relationship of this myocardial depressant substance to survival of the patient deserves specific consideration. In a previous publication (17), we noted the somewhat paradoxical finding that septic shock patients with an initially depressed EF had a higher survival than patients with an initially normal or elevated EF. As can be seen in Figs. 4, 5, and 7, a normal or high EF was seen in many of the nonsurvivors. However, when we specifically analyzed the quantity of myocardial depression (extent and velocity of shortening) in vitro during the acute phase of septic shock, there were no significant differences between the survivors and nonsurvivors. Thus, although the amount of myocardial depressant substance positively correlated with the profound effect on ventricular function, the circulating depressant did not show a significant correlation with the survival in these patients. The relationship between myocardial depressant substance and prognosis will require further study and a better understanding of both the structure and function of this circulating depressant substance.

\section{Acknowledgments}

The authors wish to express their sincere appreciation to Mrs. Elizabeth Ashbaugh, Mrs. Marian Jasch, Ms. Susan Oremland, Ms. Sandra Montgomery, and Ms. Sue LaRoche for excellent secretarial assistance; to Dr. David Alling for his outstanding advice regarding statistical analysis; to Ms. Terri Schlesinger and Mrs. Patricia Roach for their excellent technical assistance; to Dr. Michael Kaliner for his advice regarding the chemical isolation of myocardial depressant substances; to Dr. Robert $\mathrm{O}$. Bonow for referral of several control patients with structural heart disease; and to Dr. Anthony S. Fauci and Dr. Henry Masur for their review of the manuscript.

\section{References}

1. McCabe, W. R., B. E. Kreger, and M. Johns. 1972. Type specific and cross-reactive antibodies in gram negative bacteremia. $N$. Engl. J. Med. 287:261-266.

2. Wolff, S. M., and J. V. Bennett. 1974. Gram-negative rod bacteremia (editorial). N. Engl. J. Med. 291:733-734.

3. Waisbren, B. A. 1951. Bacteremia due to gram-negative bacilli other than the salmonella. AMA Arch. Intern. Med. 88:467-488.

4. Weil, M. H., L. D. MacLean, M. B. Visscher, and W. W. Spink. 1956. Studies on the circulatory changes in the dog produced by endotoxin from gram-negative microorganisms. J. Clin. Invest. 35:1191-1198.

5. Udhoji, V. N., and M. H. Weil. 1965. Hemodynamic and metabolic studies on shock associated with bacteremia. Ann. Intern. Med. 62:966978.

6. Nishijima, H., M. H. Weil, H. S. Lubin, and J. Cavanilles. 1973. Hemodynamic and metabolic studies on shock associated with gramnegative bacteremia. Medicine (Baltimore). 52:287-294.

7. Wilson, R. F., A. P. Thal, P. H. Kindling, T. Grifka, and E. Ackerman. 1965. Hemodynamic measurements in septic shock. Arch. Surg. 91:121-129.

8. MacLean, L. D., W. G. Mulligan, A. P. H. McLean, and J. H. Duff. 1967. Patterns of septic shock in man-a detailed study of 56 patients. Ann. Surg. 166:543-562.

9. Sibbald, W. J., N. A. M. Paterson, R. L. Holliday, R. A. Anderson, T. R. Lobb, and J. H. Duff. 1978. Pulmonary hypertension in sepsis. Measurement by the pulmonary arterial diastolic-pulmonary wedge pressure gradient and the influence of passive and active factors. Chest. 73:583-591.

10. Parrillo, J. E. 1984. Septic shock: clinical manifestations, pathogenesis, hemodynamics, and management in a critical care unit. In Major Issues in Critical Care Medicine. J. E. Parrillo, and S. M. Ayres, editors. Williams \& Wilkins Co., Baltimore. 111-125.

11. Winslow, E. J., H. S. Loeb, S. H. Rahimtoola, S. Kamath, and R. M. Gunnar. 1973. Hemodynamic studies and results of therapy in 50 patients with bacteremic shock. Am. J. Med. 54:421-433.

12. Siegel, J. H., M. Greenspan, and L. R. Del Guckeio. 1967. Abnormal vascular tone, defective oxygen transport and myocardial failure in human septic shock. Ann. Surg. 165:504-517.

13. Clowes, G. H., G. H. Farrington, W. Zuschneid, G. R. Cossette, and C. Saravis. 1970. Circulating factors in the etiology of pulmonary insufficiency and right heart failure accompanying severe sepsis (peritonitis). Ann. Surg. 171:663-678.

14. Hess, M. L., A. Hastillo, and L. J. Greenfield. 1981. Spectrum of cardiovascular function during gram-negative sepsis. Prog. Cardiovasc. Dis. 23:279-298.

15. Weisel, R. D., L. Vito, R. C. Dennis, C. R. Valeri, and H. B. Hechtman. 1977. Myocardial depression during sepsis. Am. J. Surg. 133: 512-521.

16. Harris, P. J., F. E. Harrel, K. L. Lee, V. S. Behar, and R. A. Rosati. 1979. Survival in medically treated coronary artery disease. Circulation. 600:1259-1266.

17. Parker, M. M., J. H. Shelhamer, S. L. Bacharach, M. V. Green, C. Natanson, T. M. Frederick, B. A. Damske, and J. E. Parrillo. 1984. Profound but reversible myocardial depression in patients with septic shock. Ann. Intern. Med. 100:483-490.

18. Calvin, J. E., A. A. Driedger, and W. J. Sibbald. 1981. An assessment of myocardial function in human sepsis utilizing ECG gated cardiac scintigraphy. Chest. 38:579-586.

19. Cunnion, R. E., G. L. Schaer, L. Miller, C. Natanson, M. M. Parker, C. L. Hanson, G. D. Morrison, and J. E. Parrillo. 1984. Coronary 
blood flow and myocardial lactate extraction in patients with shock. Crit. Care Med. 12:310 (Abstr.)

20. Borer, J. S., S. L. Bacharach, M. V. Green, K. M. Kent, S. E. Epstein, and G. S. Johnston. 1977. Real-time radionuclide cineangiography in the non-invasive evaluation of global and regional left ventricular function at rest and during exercise in patients with coronary artery disease. N. Engl. J. Med. 296:839-844.

21. Harary, I., and B. Farley. 1960. In vitro studies of single isolated beating heart cells. Science (Wash. DC). 131:1674-1675.

22. Boder, G. B., R. J. Harley, and I. S. Johnson. 1971. Recording system for monitoring automaticity of heart cells in culture. Nature (Lond.). 231:531-532.

23. Harary, I., and B. Farley. 1963. In vitro studies on single beating rat heart cells. Exp. Cell Res. 29:451-465.

24. Harary, I., R. McCarl, and B. Farley. 1966. Studies in vitro on single beating rat heart cells. IX. The restoration of beating by serum lipids and fatty acids. Biochim. Biophys. Acta. 115:15-22.

25. Biedert, S., W. H. Barry, and T. W. Smith. 1979. Inotropic effects and changes in sodium and calcium contents associated with inhibition of monovalent cation active transport by ouabain in cultured myocardial cells. J. Gen. Physiol. 74:479-494.

26. Barry, W. H., R. Pitzen, K. Protas, and D. C. Harrison. 1975. Inotropic effects of different calcium ion concentrations on the embryonic chick ventricle. Comparison of single cultured cells and intact muscle strips. Circ. Res. 36:727-734.

27. Thompson, E. J., S. H. Wilson, W. H. Schuette, W. C. Whitehouse, and M. W. Nirenberg. 1973. Measurement of the rate and velocity of movement by single heart cells in culture. Am. J. Cardiol. 32:162-166.

28. De Haan, R. L. 1967. Regulation of spontaneous activity and growth of embryonic chick heart cells in tissue culture. Dev. Biol. 16: 216-249.

29. Lefer, A. M. 1970. Role of a myocardial depressant factor in the pathogenesis of circulatory shock. Fed. Proc. 29:1836-1847.

30. Lefer, A. M., and J. Martin. 1970. Origin of myocardial depressant factor in shock. Am. J. Physiol. 218:1423-1427.

31. Glucksman, E. E., and A. M. Lefer. 1971. Effects of a myocardial depressant factor on isolated vascular smooth muscle. Am. J. Physiol. 220:1581-1585.

32. Lefer, A. M. 1982. The pathophysiologic role of myocardial depressant factor as a mediator of circulatory shock. Klin. Wochenschr. 60:713-716.
33. Maksad, A. K., C. Chung-Ja, R. C. Stuart, F. A. Brosco, and G. H. A. Clowes, Jr. 1979. Myocardial depression in septic shock: Physiologic and metabolic effects of a plasma factor on an isolated heart. Circ. Shock Suppl. 1:35-42.

34. McConn, R., J. K. Greineder, F. Wasserman, and G. H. A. Clowes, Jr. 1979. Is there a humoral factor that depresses ventricular function in sepsis? Circ. Shock Suppl. 1:9-22.

35. Carli, A., M. C. Auclair, C. Vernimmen, and P. Jourdon. 1979. Reversal by calcium of rat heart cell dysfunction induced by human sera in septic shock. Circ. Shock Suppl. 6:147-157.

36. Carli, A., M. C. Auclair, G. Bleichner, S. Weber, P. Lechat, and J. F. Monsallier. 1978. Inhibited response to isoproterenol and altered action potential of beating rat heart cells by human serum in septic shock. Circ. Shock Suppl. 5:85-94.

37. Greene, L. J., R. Shapanka, T. M. Glenn, and A. M. Lefer. 1977. Isolation of myocardial depressant factor from plasma of dogs in hemorrhagic shock. Biochim. Biophys. Acta. 491:275-285.

38. Hinshaw, L. B. 1979. Myocardial function in endotoxin shock. Circ. Shock Suppl. 1:43-51.

39. Abboud, F. M. 1982. Shock. In Cecil Textbook of Medicine, 16th edition. J. B. Wyngaarden and L. H. Smith, Jr., editors. W. B. Saunders Company, Philadelphia. 155-168.

40. Wangensteen, S. L., W. G. Ramey, W. W. Ferguson, and J. R. Starling. 1973. Plasma myocardial depessant activity (shock factor) identified as salt in the cat papillary muscle bioassay system. J. Trauma. 13:181-194.

41. Parrillo, J. E. 1985. Cardiovascular dysfunction in septic shock: new insights into a deadly disease. Int. J. Cardiol. 7:314-321.

42. Parker, M. M., J. H. Shelhamer, C. Natanson, L. Miller, H. Masur, and J. E. Parrillo. 1983. Serial hemodynamic patterns in survivors and non-survivors of septic shock in humans. Clin. Res. 31:671A. (Abstr.)

43. Ognibene, F. P., M. M. Parker, C. Natanson, A. Keenan, B. Damske, G. White, T. Schlesinger, and J. E. Parrillo. 1985. Depressed left ventricular performance in response to volume infusion in patients with sepsis. Clin. Res. 33:294A. (Abstr.)

44. Rackow, E. C., B. S. Kaufman, J. L. Falk, M. E. Astiz, and M. H. Weil. 1985. Reversible myocardial dysfunction in patients with septic shock. Clin. Res. 33:295A. (Abstr.)

45. Clowes, Jr., G. H. A., B. C. George, C. A. Villee, Jr., and C. A. Saravis. 1983. Muscle proteolysis induced by a circulating peptide in patients with sepsis or trauma. N. Engl. J. Med. 308:545-588. 